\title{
Morpho-anatomical and biochemical changes associated with rooting of micropropagated ninebark cuttings
}

\author{
Katarzyna Jagiełło-Kubiec ${ }^{1} \cdot$ Karolina Nowakowska $^{1} \cdot$ Aleksandra Józefina Łukaszewska $^{1} \cdot$ Andrzej Pacholczak ${ }^{1}$ (D)
}

Received: 3 September 2020 / Accepted: 1 June 2021 / Published online: 20 July 2021

(c) The Author(s) 2021

\begin{abstract}
Ninebark (Physocarpus opulifolius) is an attractive ornamental shrub with poor rooting characteristics in some cultivars, which is a limiting factor in commercial production This study was designed to optimize rooting conditions of ninebark cuttings and to observe the effect of exogenous auxin IBA on some morpho-anatomical and biochemical changes associated with rhizogenesis in the in vitro conditions. Both auxins under study: the indole-3-butyric acid (IBA) and 1-naphthalene acetic acid (NAA) gave comparable effects but the combination of $1 / 2 \mathrm{MS}+1 \mathrm{mg} \cdot \mathrm{L}^{-1}$ IBA was the most cost effective for all rooting parameters. Anatomical changes at the cuttings' bases during root formation were typical for woody plants and they were accelerated by auxin in the culture medium. High levels of the endogenous indole acid and hydrogen peroxide were temporarily associated with intensive cell divisions in cuttings, and the polyphenolic acid contents kept increasing during rooting above the initial levels and those in controls.
\end{abstract}

\section{Key message}

Results of this work show that micropropagation may be the answer to growing demand for ninebark stocks. Anatomical changes occurring at the bases of stem cuttings during root formation in vitro are typical for woody plants. Auxin in the rooting medium accelerated individual phases of rhizogenesis making it shorter and more efficient. High levels of the endogenous indole acid and hydrogen peroxide were transiently associated with intensive cell divisions in cuttings. In auxin-treated cuttings, the polyphenolic acid contents increased during rooting above the initial levels and those in non-treated cuttings.

Keywords Root primordia anatomy $\cdot$ Indole acid $\cdot$ Hydrogen peroxide $\cdot$ Polyphenolic acids $\cdot$ Rhizogenesis

\section{Introduction}

Ninebark (Physocarpus opulifolius) has recently gained enormous popularity and its decorative and easy-to-grow cultivars are massively planted in green areas. However, its conventional propagation methods are not sufficiently effective as the rooting rate of stem cuttings ranges widely among cultivars $(50 \%-85 \%)$, at times falling below the economic threshold of ca. 50\% (Pacholczak and Szydło 2008). The in vitro micropropagation appears as an effective alternative

Communicated by Barbara Mary Doyle Prestwich.

Andrzej Pacholczak

andrzej_pacholczak@sggw.edu.pl

1 Institute of Horticultural Sciences, Section of Ornamental Plants, Warsaw University of Life Sciences (SGGW), 159 Nowoursynowska str, 02-776 Warsaw, Poland to the standard propagation by cuttings, as it is capable of producing large quantities of the true-to-type plant material. No data was available on ninebark micropropagation till 2013 when we published the first results on the effects of different sugars as carbon sources on proliferation of ninebark in vitro cultures (Ilczuk et al. 2013). However, in all micropropagation approaches, rooting of cuttings is a critical step, especially so in woody plants where adventitious root development is more difficult than in herbaceous species. An inability to induce adventitious roots may be a barrier to in vitro propagation of trees and shrubs (Yan et al. 2010; Shekhawat and Manokari 2016).

Adventitious roots are formed from cells adjacent to xylem, or its elements such as cells of phloem or wood, cambium, or cells connecting cambium and phloem (close to the hormone and carbohydrate sources). In cuttings of some plants, root primordia can be formed from the parenchyma tissues present near the wound, or from callus produced 
there (Pacurar et al. 2014). The reports on ninebark micropropagation are still scarce and the origin of the adventitious roots has not been investigated.

There is a relationship between adventitious root formation and the endogenous auxin levels and the polyphenolic acid contents (Fu et al. 2011). It is generally accepted that dedifferentiation and root primordia formation are accompanied by an increase in the endogenous indole-3-acetic acid level (IAA) (Wei et al. 2019). In flax (Linum usitatissimum), the levels of endogenous IAA were positively correlated with increased root formation in response to exogenous auxin NAA (1-naphthalene acetic acid) (Tomač et al. 2016).

Phenolic compounds are common in plants as secondary metabolites with many roles in plant development. It has been known for decades that they may act as rooting co-factors (Szydło et al. 2007). Di- and polyphenolic compounds are active antioxidants protecting IAA against oxidation and the tissue against oxidative stress induced mainly by stem wounding (De Klerk et al. 1999; De Klerk et al. 2011).

Hydrogen peroxide is also positively correlated with root formation, by regulating the endogenous auxin level (Tomač et al. 2016). $\mathrm{H}_{2} \mathrm{O}_{2}$ is one of the reactive oxygen species (ROS) generated under unfavorable environmental conditions, including wounding, which occurs when shoots are severed off the stock plants and cuttings are prepared. ROS play important roles in plant developmental processes and signal transduction. In Arabidopsis, the oxidative stress enhances the auxin driven cell divisions, cluster formation, and/or lateral root formation (Pasternak et al. 2005). According to Huang et al. (2019) the wound-induced ROS participate in adventitious root induction in Arabidopsis through regulation of auxin biosynthesis and transport. According to Tsukagoshi (2016) ROS regulate the root meristem activity, tip growth of the root hair, and the lateral root development. Direct involvement of hydrogen peroxide in root formation was also shown in cucumber (Li et al. 2007) and in mung bean (Li et al. 2009).

Given increasing popularity of ninebark (Physocarpus opulifolius) and limited data on its micropropagation, this study was designed to optimize the conditions for the in vitro rooting of cuttings and to observe the effect of exogenous auxin IBA on some morpho-anatomical and biochemical changes associated with rhizogenesis.

\section{Material and methods}

The experimental material were the apical segments of shoots collected from established 8-10 week old in vitro cultures of ninebark cv. DIABLE D'OR 'Mindia' growing on the MS medium (Murashige and Skoog 1962) with $1 \mathrm{mg} \cdot \mathrm{L}^{-1} \mathrm{BA}$ and $0.1 \mathrm{mg} \cdot \mathrm{L}^{-1} \mathrm{NAA}$ (Jagiello-Kubiec et al. 2021). Sorbitol was used as the carbon source as it proved more suitable than fructose (Jagiello-Kubiec et al. 2021). Shoot tips at least $1.5 \mathrm{~cm}$ long were placed onto the rooting medium ( $1 / 2 \mathrm{MS})$. After 8 weeks the following parameters were scored: $\%$ of rooted microcuttings, the mean number of roots per microcutting, and the mean root length. Each treatment contained 10 replications with 5 plants in each (50 in total).

To test the effect of the macronutrient concentration in the in vitro rooting medium the explants were placed onto the medium containing different concentrations of the MS macronutrients and $1 \mathrm{mg} \cdot \mathrm{L}^{-1}$ IBA. To check the effects of the type and concentration of auxins, microcuttings were placed onto $1 / 2 \mathrm{MS}$ with IBA or NAA in concentrations: 0.1 , $0.5,1.0,2.0,3.0 \mathrm{mg} \cdot \mathrm{L}^{-1}$ while the control medium did not contain auxins.

\section{Biochemical analyses}

Plants for biochemical analyses were cultured on $1 / 2$ MS with or without $1 \mathrm{mg} \cdot \mathrm{L}^{-1}$ IBA. The above-ground parts of microcuttings were sampled on day 0 and every 5 days during the 30 days of culture. The material was finely chopped, mixed, and 3 samples of $0.25 \mathrm{~g}$ each were weighted for each analysis. Three extractions were done for each analysis and 3 measurements were made for each extract, producing 9 data points. The hydrogen peroxide concentration was measured according to Pick and Keisari (1980), endogenous IAA and its derivatives by the colorimetric method described by Gordon and Weber (1951) polyphenolic acids according to the Polish norm PN-91/R-87019 (2002). Absorbance was measured with the spectrophotometer UV-1601 PC (Schimadzu).

\section{Histological analyses}

Basal segments $(1.0 \mathrm{~cm})$ were sampled from shoots in the control treatment and the treatment with $1 \mathrm{mg} \cdot \mathrm{L}^{-1}$ IBA. Samples were collected daily from Day 0 to Day 15 of the experiment. Explants were fixed in FAA (a 16:5:50 v/v/v mixture of formaldehyde, glacial acetic acid, 96\% ethanol), dehydrated through graded ethanol and xylene series, and embedded in paraffin wax (Jensen 1962). Sections $(10 \mu \mathrm{m})$ were cut and stained with safranin-fast green. Photographs were taken under the OLYMPUS BX-41 microscope equipped with OLYMPUS CAMEDIA C5050 with a threefold optical magnification and 5 mega pixel matrix, and recorded in the jpg format.

\section{Statistical analysis}

All results were subjected to the analysis of variance using the Statgraphics Centurion XVI (Statgraphics Technologies Inc., The Plains, VA, USA), after the Shapiro-Wilk test. Bliss transformation was performed for all data in 
percentages (Compton 1994). Experimental data were subjected to one- or two-way analysis of variance and then to Duncan's multiple range test to separate the means at the significance level at $\alpha=0.05$ (Wójcik and Laudański 1989).

\section{Results}

\section{Rooting of microcuttings}

The auxin type and concentration significantly affected rooting parameters (Table 1). The percentage of rooted cuttings ranged between 76 and $96 \%$. The lowest proportion of rooted cuttings was in the control treatment and on the medium supplemented with IBA in the lowest or the highest concentration. No significant differences were found between cuttings rooted on the media with different NAA concentrations: all rooted in the $86-96 \%$ range. The lowest number (4.2 roots) of the shortest $(0.4 \mathrm{~cm})$ roots were in cuttings growing with $0.1 \mathrm{mg} \cdot \mathrm{L}^{-1}$ IBA while the highest number of roots was in the presence of $1-3 \mathrm{mg} \cdot \mathrm{L}^{-1}$ IBA $(9.8-10.8$ roots per cutting) or $1 \mathrm{mg} \cdot \mathrm{L}^{-1} \mathrm{NAA}$ (10.9 roots). The longest roots grew on the medium with $1-3 \mathrm{mg} \cdot \mathrm{L}^{-1}$ IBA $(1.5-1.6 \mathrm{~cm})$ or $0.5 \mathrm{mg} \cdot \mathrm{L}^{-1}$ NAA $(1.4 \mathrm{~cm})$.

The macronutrient concentration significantly affected rooting (Table 2). The poorest results were on the medium with the macronutrient concentration lowered to $1 / 4$, where $72 \%$ cuttings formed roots averaging $0.9 \mathrm{~cm}$ in length and with 5.9 roots per cutting. On $1 / 2 \mathrm{MS}$ and $1 \mathrm{MS}, 94 \%$ and $92 \%$ cuttings produced roots, respectively, numbering 10.6 and 10.9 per cutting, and 1.8 and $1.6 \mathrm{~cm}$ in length, respectively.

Table 1 The effect of the auxin type and concentration on rooting parameters in ninebark DIABLE D'OR 'Mindia'. The rooting medium was $1 / 2 \mathrm{MS}$

\begin{tabular}{llcl}
\hline Treatment & $\begin{array}{l}\text { \% of rooted } \\
\text { cuttings }\end{array}$ & Root number & Root length $[\mathrm{cm}]$ \\
\hline 0 IBA, NAA & $80.0 \mathrm{a}^{*}$ & $6.8 \mathrm{~b}$ & $1.0 \mathrm{~cd}$ \\
$0.1 \mathrm{IBA}$ & $76.0 \mathrm{a}$ & $4.2 \mathrm{a}$ & $0.4 \mathrm{a}$ \\
$0.5 \mathrm{IBA}$ & $88.0 \mathrm{ab}$ & $7.1 \mathrm{bc}$ & $0.7 \mathrm{~b}$ \\
1 IBA & $96.0 \mathrm{~b}$ & $10.8 \mathrm{~d}$ & $1.6 \mathrm{f}$ \\
2 IBA & $96.0 \mathrm{~b}$ & $10.5 \mathrm{~d}$ & $1.5 \mathrm{ef}$ \\
3 IBA & $78.0 \mathrm{a}$ & $9.8 \mathrm{~d}$ & $1.5 \mathrm{ef}$ \\
0.1NAA & $96.0 \mathrm{~b}$ & $8.3 \mathrm{c}$ & $1.3 \mathrm{e}$ \\
0.5 NAA & $96.0 \mathrm{~b}$ & $8.1 \mathrm{c}$ & $1.4 \mathrm{ef}$ \\
1 NAA & $96.0 \mathrm{~b}$ & $10.9 \mathrm{~d}$ & $1.3 \mathrm{de}$ \\
2 NAA & $88.0 \mathrm{ab}$ & $6.2 \mathrm{~b}$ & $0.9 \mathrm{bc}$ \\
3 NAA & $86.0 \mathrm{ab}$ & $6.3 \mathrm{~b}$ & $0.6 \mathrm{ab}$ \\
Mean & 89.0 & 8.1 & 1.1 \\
\hline
\end{tabular}

*Means in the columns followed by the same letter do not differ significantly at $\alpha=0.05$
Table 2 The effect of macronutrient concentration in MS on rooting of cuttings in cv. DIABLE D'OR 'Mindia'

\begin{tabular}{llcl}
\hline Treatment & $\begin{array}{l}\text { \% of rooted } \\
\text { cuttings }\end{array}$ & Root number & Root length $[\mathrm{cm}]$ \\
\hline $1 / 4 \mathrm{MS}$ & $72.0 \mathrm{a}^{*}$ & $5.9 \mathrm{a}$ & $0.9 \mathrm{a}$ \\
$1 / 2 \mathrm{MS}$ & $94.0 \mathrm{~b}$ & $10.6 \mathrm{~b}$ & $1.8 \mathrm{~b}$ \\
$1 \mathrm{MS}$ & $92.0 \mathrm{~b}$ & $10.9 \mathrm{~b}$ & $1.6 \mathrm{~b}$ \\
Mean & 86.0 & 9.1 & 1.4 \\
\hline
\end{tabular}

*Means in a column followed by the same letter do not differ significantly at $\alpha=0.05$

\section{Biochemical changes during rooting}

Generally, the presence of IBA in the rooting medium did not affect the endogenous IAA level in cuttings, except on a single date-Day 5 (Table 3). Cuttings on the MS " 0 " medium had the highest auxin content on the fifth day of the culture and this amount did not differ from that on the last day. Also, in the IBA-treated cuttings, the highest auxin content was observed on Day 5, twice as high as on Day 0. All other values in this treatment did not differ significantly from one another, nor did they differ from the respective results in the control treatment (Table 3). The polyphenolic acids content was significantly affected by the addition of auxin (IBA) to the medium. Higher values, irrespective of the day the material was collected on, were in microcuttings taken from the auxin medium than in MS without auxin.

Significant changes in the polyphenolic acids content were observed depending on the day of collection. The highest level was recorded 15 days after rooting initiation, on Days 20-25 of the experiment. After that, the levels dropped again (Table 4).

The day of collection as well as the nutrient medium composition had a significant impact on the hydrogen peroxide

Table 3 Changes in endogenous indole acids $\left[\mu \mathrm{g} \cdot \mathrm{g}^{-1}\right.$ F.W.] during rooting in ninebark DIABLE D'OR 'Mindia'

\begin{tabular}{|c|c|c|c|}
\hline \multirow[t]{2}{*}{ Culture days } & \multicolumn{2}{|l|}{ Medium } & \multirow[t]{2}{*}{ Means for day } \\
\hline & $1 / 2$ MS 0 & $\begin{array}{l}1 / 2 \\
\mathrm{MS}+1 \mathrm{mg} \cdot \mathrm{L}^{-1} \\
\text { IBA }\end{array}$ & \\
\hline 0 & $54.93 \mathrm{bc}^{*}$ & $54.93 \mathrm{bc}$ & $54.93 \mathrm{a}$ \\
\hline 5 & $76.27 \mathrm{~d}$ & $114.15 \mathrm{e}$ & $95.21 \mathrm{~b}$ \\
\hline 10 & $49.24 \mathrm{abc}$ & $42.64 \mathrm{ab}$ & $45.94 \mathrm{a}$ \\
\hline 15 & $46.69 \mathrm{abc}$ & $34.60 \mathrm{a}$ & $40.65 \mathrm{a}$ \\
\hline 20 & $52.59 \mathrm{bc}$ & $39.42 \mathrm{ab}$ & $56.01 \mathrm{a}$ \\
\hline 25 & $45.35 \mathrm{abc}$ & $36.27 \mathrm{a}$ & $40.81 \mathrm{a}$ \\
\hline 30 & $61.06 \mathrm{~cd}$ & $45.82 \mathrm{abc}$ & $53.44 \mathrm{a}$ \\
\hline Means for medium & $55.16 \mathrm{a}$ & $52.54 \mathrm{a}$ & \\
\hline
\end{tabular}

*Means followed by the same letter do not differ significantly $\alpha=0.05$ 
Table 4 Changes in contents of polyphenolic acids $\left[\mathrm{mg} \cdot \mathrm{g}^{-1}\right.$ F.W.] during rooting of ninebark DIABLE D'OR 'Mindia'

\begin{tabular}{lccc}
\hline Day & \multicolumn{2}{l}{ Medium } & Means for day \\
\cline { 2 - 3 } & $1 / 2 \mathrm{MS} 0$ & \multicolumn{1}{l}{$1 / 2 \mathrm{MS}+1 \mathrm{mg} \cdot \mathrm{L}^{-1}$} & \\
\hline & & IBA & \\
\hline 5 & $8.75 \mathrm{bcd}^{*}$ & $8.75 \mathrm{bcd}$ & $8.75 \mathrm{ab}$ \\
5 & $7.46 \mathrm{abc}$ & $6.89 \mathrm{ab}$ & $7.17 \mathrm{a}$ \\
10 & $6.73 \mathrm{a}$ & $8.92 \mathrm{~cd}$ & $7.83 \mathrm{ab}$ \\
15 & $8.95 \mathrm{~cd}$ & $10.04 \mathrm{~d}$ & $9.50 \mathrm{~b}$ \\
20 & $8.82 \mathrm{bcd}$ & $16.38 \mathrm{e}$ & $12.60 \mathrm{c}$ \\
30 & $10.26 \mathrm{~d}$ & $15.14 \mathrm{e}$ & $12.70 \mathrm{c}$ \\
Means for & $7.62 \mathrm{abc}$ & $9.70 \mathrm{~d}$ & $8.66 \mathrm{ab}$ \\
medium & $8.37 \mathrm{a}$ & $10.83 \mathrm{~b}$ & \\
\hline
\end{tabular}

*Means followed by the same letter do not differ significantly $\alpha=0.05$

content in microcuttings. The $\mathrm{H}_{2} \mathrm{O}_{2}$ content in control cuttings increased by one third on Day 5 and dropped considerably on the next collection date (Table 5). After a transitory rise on Day 15 its contents fell down. Also in the IBA-treated cuttings the highest hydrogen peroxide content was on Day 5. This content kept falling on for successive dates, to increase on the last date of the study, to a level significantly higher than on Day 0 , and by one third higher than in control cuttings (from MS "0").

\section{Macroscopic changes during rooting}

No changes in stem bases were noticeable in the explants placed onto the IBA-supplemented medium until Day 5. Between Days 6 and 10, the stem bases started to swell. On Day 8, the first roots pierced the epidermis. In explants on the control medium (no auxin) these events were retarded:

Table 5 Changes in contents of hydrogen peroxide [ $\mu \mathrm{g} \cdot \mathrm{g}$ F.W. ${ }^{-1}$ ] during rooting of ninebark DIABLE D'OR 'Mindia'

\begin{tabular}{|c|c|c|c|}
\hline \multirow[t]{2}{*}{ Day } & \multicolumn{2}{|l|}{ Medium } & \multirow[t]{2}{*}{ Means for day } \\
\hline & $1 / 2 \mathrm{MS} 0$ & $\begin{array}{l}1 / 2 \mathrm{MS}+1 \mathrm{mg} \cdot \mathrm{L}^{-1} \\
\text { IBA }\end{array}$ & \\
\hline 0 & $890.53 \mathrm{~d}^{*}$ & $890.53 \mathrm{~d}$ & 890.53 b \\
\hline 5 & $1261.29 \mathrm{~d}$ & $1383.86 \mathrm{~g}$ & $1322.57 \mathrm{c}$ \\
\hline 10 & $697.07 \mathrm{~b}$ & $1153.45 \mathrm{e}$ & $925.26 \mathrm{~b}$ \\
\hline 15 & $896.84 \mathrm{~d}$ & $927.72 \mathrm{~d}$ & $912.28 \mathrm{~b}$ \\
\hline 20 & $665.73 \mathrm{ab}$ & $809.36 \mathrm{c}$ & $737.55 \mathrm{a}$ \\
\hline 25 & $636.49 \mathrm{ab}$ & $622.22 \mathrm{a}$ & $629.36 \mathrm{a}$ \\
\hline 30 & 807.72 c & $1101.29 \mathrm{e}$ & $954.50 \mathrm{~b}$ \\
\hline $\begin{array}{l}\text { Means for } \\
\text { medium }\end{array}$ & $836.53 \mathrm{a}$ & $984.06 \mathrm{~b}$ & \\
\hline
\end{tabular}

*Means followed by the same letter do not differ significantly $\alpha=0.05$ no visible changes were apparent between Days 1-7, swelling of stem bases occurred between Days 8 and 12, and the first roots started to appear from Day 13 on. More roots developed on cuttings supplemented with the auxin.

\section{Microscopic changes during rooting}

Anatomic changes observed in stems cultured with or without auxin IBA in the rooting medium are listed in Table 6.

\section{Day 0}

On the cross section of stem bases the following structural elements could be distinguished: pith, xylem, cambium, phloem, cortex and epidermis (Fig. 1a). When placed on the rooting medium, stems initiated their secondary growth. The organization of the epidermis, cortex and pith cells was normal while the cambium cells were heavily vacuolized. These cells contained little cytoplasm, sparse cellular structures and peripherally positioned flattened nucleus. Pith cells were circular and heavily vacuolized. The cortex cells were slightly flattened.

\section{Induction phase}

$24 \mathrm{~h}$ after the IBA application the first starch granules appeared in the vascular bundles, in pith cells and cortex as well as in cambium where they occupied a considerable cell area. No other anatomical changes were observable during Days 1-3 (Fig. 1a). In explants not treated with auxin, starch granules appeared later, between Days 1 and 4, and in lower numbers.

\section{Initiation phase}

Between Days 4 and 6 after placing cuttings onto the IBA containing rooting medium several groups of cells with reduced, dense and strongly stained cytoplasm, and conspicuous nuclei, were visible in the cambium region (Fig. 1b). Intensive cell divisions were evident. Before division, nuclei

Table 6 Acceleration of anatomic changes occurring in stem bases of ninebark DIABLE D'OR 'Mindia' during rooting due to presence of IBA in the rooting medium

\begin{tabular}{lll}
\hline Anatomic changes in cuttings & \multicolumn{2}{l}{ Rooting medium $1 / 2 \mathrm{MS}$} \\
\cline { 2 - 3 } & $1 \mathrm{mg} \cdot \mathrm{L}^{-1} \mathrm{IBA}$ & 0 IBA \\
\hline Absence of noticeable changes & Day 1-3 & Day 1-4 \\
Intensive cell divisions & Day 4-6 & Day 5-9 \\
Formation of root primordia & Day 6-9 & Day 10-12 \\
Roots piercing the epidermis & Day 8-12 & Day 13-15 \\
Root elongation & Day 12< & Day 14< \\
\hline
\end{tabular}


became round and were located centrally. Cells undergoing divisions had isodiametric dimensions. In cambium cells, the divisions were mostly transverse. On successive days (Days 6-9) cell divisions in the cambium region were more active (Fig. 1c). Groups of dividing cells (meristemoids) became oval in shape and were found to be differentiated into the root primordia (Fig. 1d). These primordia were elongating perpendicularly to the main axis towards the epidermis, pushing aside the phloem elements. Root primordia kept expanding due to continuous cell divisions, forming bulges at the stem base.

\section{Expression phase}

Between Days 8 and 12 of the culture on the IBA-containing medium, the root primordia were piercing through the epidermis and started to appear outside the explant (Fig. 1e,f). Groups of cells forming semicircular caps were noticeable at the root tips (Fig. 1f). In some root primordia, tracheal elements were already visible. Their connections with the shoot vascular bundles were also observed (Fig. 1f, g). Further root elongation continued after Day 12 (Fig. 1h). In cuttings rooted without auxin, piercing of roots through the epidermis was observed from Day 13 on.

\section{Discussion}

Ninebark cultivars differ in their rooting abilities, ranging from poor to acceptable (Pacholczak and Szydło 2008). Among these, cv. DIABLE D'OR 'Mindia' was one of the poorest, with only $26 \%$ success rate with no rooting enhancers applied to semi-lignified cuttings (Pacholczak 2015). In response to a growing demand for ninebark planting material, micropropagation appears as a promising alternative. Exogenous auxins present in a rooting medium improve rhizogenesis (Wei et al. 2019; Jagiello-Kubiec et al. 2021). Auxins act with other phytohormones modulating their action on several levels: biosynthesis, metabolism, transport and signaling (Lakehal and Bellini 2019). In micropropagation, the 3-indole-butyric acid (IBA) is mainly used; the indole-3-acetic acid level (IAA) and the 1-naphthalene acetic acid (NAA) are considered less suitable (Hartmann et al. 2011). However, much depends on the species or the cultivar involved. In Ricinus communis Ahn et al. (2007) obtained comparable results with IBA or NAA. The same was true in this study: cv. DIABLE D'OR 'Mindia' tested here both IBA and NAA, in concentration of $1 \mathrm{mg} \cdot \mathrm{L}^{-1}$, increased the rooting percentage from 80 to $96 \%$. On the other hand, a yellow-leaved cv. 'Dart's Gold' rooted significantly better with IBA than NAA (Jagiello-Kubiec et al. 2021). As Ahn et al. (2007) have shown that plants rooted in the presence of IBA showed a higher rate of establishment in the soil than those rooted with NAA (93.5\% vs 39.5\% in castor bean), IBA was used for all further cultures of ninebark DIABLE D'OR 'Mindia'.

Adventitious root formation is a multi-stage process leading to the formation of new roots at the base of stem cuttings. The main plant growth regulator responsible for rooting is auxin which activates the existing root primordia or induces new ones (De Klerk et al. 1999). There are two main phases to rhizogenesis: induction, requiring a higher auxin concentration; and root formation (anatomical changes) inhibited by high concentration of auxin (Druege et al. 2016). Therefore, at the beginning of rhizogenesis in the ninebark microcuttings, on Day 5, the highest concentration of endogenous indole acids was recorded, and then, when auxin was no longer needed, its concentration dropped.

Probably the auxin added to the medium, while producing significantly more rooted microcuttings, also acted as a stress factor. This is indicated by an increased level of both, the phenolic acids and hydrogen peroxide in microcuttings rooted in the MS medium with the addition of IBA, compared to those taken from the auxin-free MS medium. In response to abiotic stresses, plants typically increase the biosynthesis of secondary metabolites, including polyphenols. Phenols give plants a higher tolerance to various stress conditions (Sharma et al. 2019). Hydrogen peroxide is one of the reactive oxygen species and is generally considered toxic to plant metabolism (Neves et al. 1998). There is evidence, however, that it also serves as a useful signal transmitter and intercedes in different biochemical and physiological processes (Yang et al. 2013). In ninebark, in both the IBA-treated and non-treated cuttings, the highest hydrogen peroxide contents were recorded on Day 5 . This might have been due to an intensive oxidative stress induced by wounding and a change in the culture medium. According to $\mathrm{Li}$ et al. (2007), $\mathrm{H}_{2} \mathrm{O}_{2}$ may stimulate formation of adventitious roots in cuttings of mung bean and cucumber, and intercede in their response to auxin during rooting ( $\mathrm{Li}$ et al. 2007; $\mathrm{Li}$ et al. 2009). A rapid increase in endogenous $\mathrm{H}_{2} \mathrm{O}_{2}$ was observed during the first 3 days of rooting of tomato cuttings while later this content decreased (Tyburski et al. 2006). Similarly, the highest level of hydrogen peroxide in this study was recorded at the start of rhizogenesis, followed by a significant reduction. Changes in the content of $\mathrm{H}_{2} \mathrm{O}_{2}$ correlated in time with the changes in the endogenous indole acids content.. This suggests that the acceleration of cell divisions, and the development of root primordia, was affected by both a higher concentration of indole acids and hydrogen peroxide (the highest content on both Day 5 days after placing on the rooting medium).

Under abiotic stresses plants show increased synthesis of polyphenols, such as phenolic acids. These capture ROS, including $\mathrm{H}_{2} \mathrm{O}_{2}$ (Sharma et al. 2019) thus increasing tolerance of stress. Here, after increasing the content of $\mathrm{H}_{2} \mathrm{O}_{2}$ 

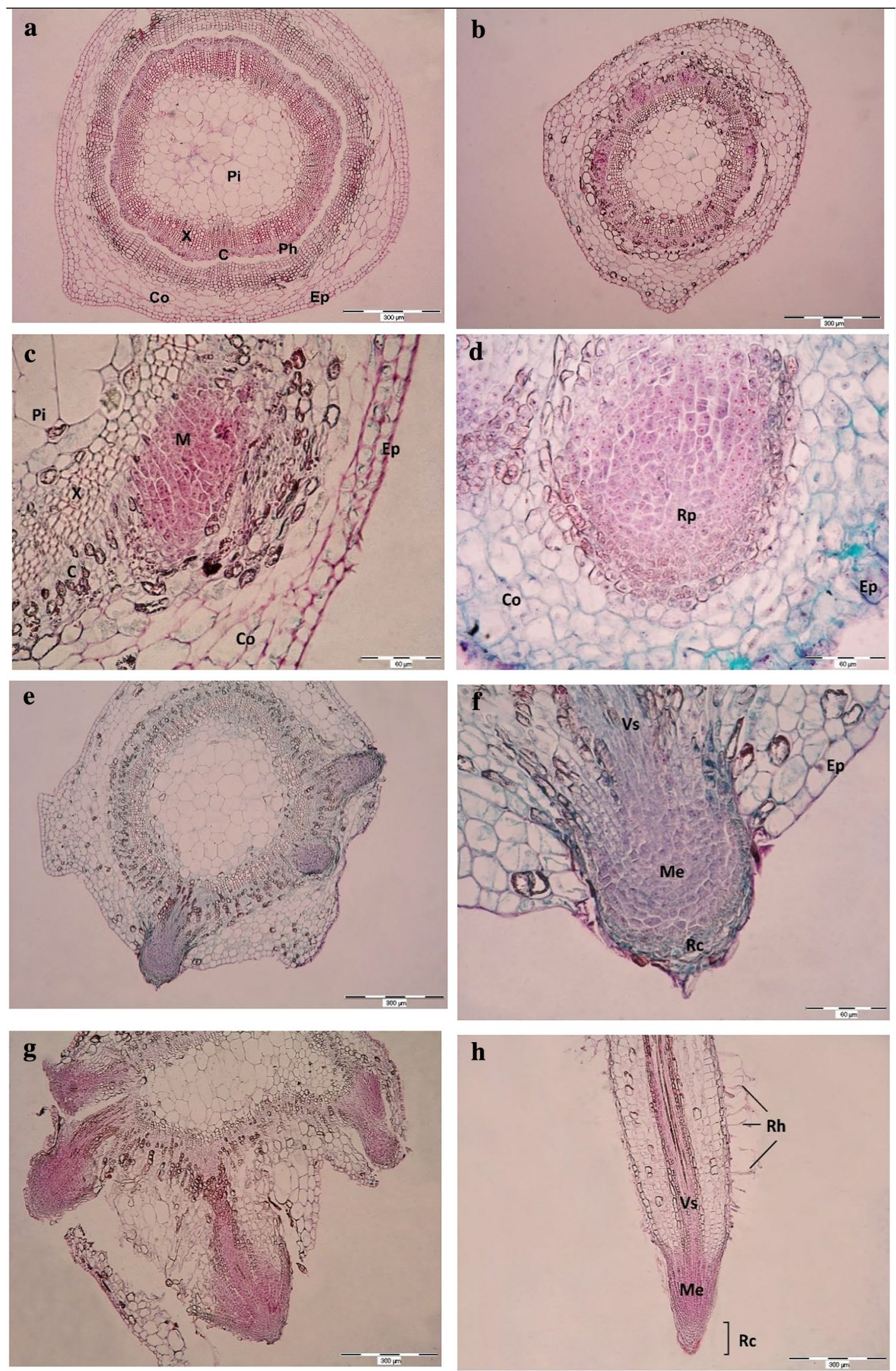
4Fig. 1 Anatomic changes occurring in bases of ninebark DIABLE D'OR 'Mindia' cuttings during rooting on the $1 / 2$ MS medium with $1 \mathrm{mg} \cdot \mathrm{L}^{-1}$ IBA: a Day 1-3: absence of noticeable changes; $\mathbf{b}$ Day 4-6: meristemoids appear; c meristemoid - group of cells differentiating into root primordium 4 days after placing onto the medium; $\mathbf{d}$ Day 6-9: dividing cells forming oval root primordium; e, f, g Day 8-12: root primordia piercing through the epidermis; $h$ longitudinal section of adventitious root on Day 12 of the culture in presence of IBA; Scale: a, b, e, g, h-300 $\mu \mathrm{m} ; \mathbf{c}, \mathbf{d}, \mathbf{f}-60 \mu \mathrm{m}$; Abbreviations: $P i$ pith; $P h$ phloem; $C$ cambium; $X$ xylem; $C o$ cortex; Ep epidermis; Rp root primordium; $M e$ root meristem; $R c$ root cap; Vs vascular system; $R h$ root hairs

in the microcuttings on Day 5, a slow increase in the content of phenolic acids followed. Their highest level was on days 20-25 of root formation, coincidental with the lowest hydrogen peroxide content. Phenolic compounds are also considered as rooting cofactors that affect root formation and development (Rout 2006; Fu et al. 2011). Phenolics can inhibit the IAA catabolism or limit the IAA synthesis (Mathesius 2001). Here, the level of polyphenolics kept increasing in the IBA-treated cuttings up to Day 25 while in the nontreated cuttings the levels were significantly lower from Day $10 \mathrm{on}$. It is generally accepted that phenolic compounds act synergistically with auxins in root initiation and formation as higher phenolics levels better protect auxin from oxidation, making it more effective.

The succession of anatomic changes during root development observed here was similar to that described for other woody plants, such as apple (Naija et al. 2008), plume (Prunus domestica L.) (Wiszniewska et al. 2016), chestnut (Castanea sativa Mill.) (Ballester et al. 1999), oak (Quercus robur L.) (Vidal et al. 2003) and smoke tree (Cotinus coggygria Scop.) (Ilczuk and Jacygrad 2016). IBA accelerated the anatomic changes in the bases of cuttings and it was the most evident at the root primordia formation and roots piercing the epidermis. With IBA present, the primordia formation began on Day 6 with roots piercing the epidermis on Day 8; on the auxin-free medium this happened 4 and 5 days later.

As listed earlier, the root primordia initiation may take place in various tissues of a cutting, depending on the species. Here, intensive cell divisions were observed in the cambium zone and this phase lasted between Days 5 and 9 without auxin; IBA accelerated it by one day. With auxin, the root primordia started to appear between Days 6 and 9 while on $1 / 2$ MS 0 , between Days 10 and 12 . The last phase of rooting i.e. expression, is the transformation of primordia into fully developed roots and their breaking through the epidermis (Naija et al. 2008). In the auxin treated ninebark, piercing of epidermis by new roots occurred between Days 8 and 12 , followed by root elongation. Without the auxin, this process was not observed before Day 13. Generally, the root development patterns were the same in both treatments (control and IBA) but in the auxin treated cuttings more meristemoids were formed, therefore more rooted cuttings with more numerous roots were obtained, and the individual phases of the entire process were accelerated by one to several days. Similar results were reported by Millán-Orozco et al. (2011) in Cedrela odorata.

This study shows that micropropagation may be the answer to growing demand for ninebark stocks. Anatomical changes occurring at the bases of ninebark cuttings during root formation in vitro are typical for woody plants. Auxin in the rooting medium stimulated and accelerated rhizogenesis. High levels of the endogenous indole acid and hydrogen peroxide were transiently associated with intensive cell divisions. In the auxin-treated cuttings, the polyphenolic acid contents increased during rooting above the initial levels and those in non-treated cuttings. However, a comparison of two ninebark cultivars - the earlier described cv.'Dart's Gold' (Jagiello-Kubiec et al. 2021) and the one tested here illustrates the necessity for a flexible approach and tailoring culture recommendations to each cultivar individually.

Authors' contributions KJ-K: conceptualization, methodology, formal analysis and writing-original draft preparation; KN: analysis and interpretation of date, writing part of manuscript; AJŁ: formal analysis, writing-original draft preparation, writing-review and editing, supervision; AP: formal analysis, writing-original draft preparation, visualization. All authors have read and agreed to the published version of the manuscript.

Funding This research received no external funding.

\section{Declarations}

Conflict of interest The authors have no conflicts of interest to declare that are relevant to the content of this article.

Open Access This article is licensed under a Creative Commons Attribution 4.0 International License, which permits use, sharing, adaptation, distribution and reproduction in any medium or format, as long as you give appropriate credit to the original author(s) and the source, provide a link to the Creative Commons licence, and indicate if changes were made. The images or other third party material in this article are included in the article's Creative Commons licence, unless indicated otherwise in a credit line to the material. If material is not included in the article's Creative Commons licence and your intended use is not permitted by statutory regulation or exceeds the permitted use, you will need to obtain permission directly from the copyright holder. To view a copy of this licence, visit http://creativecommons.org/licenses/by/4.0/.

\section{References}

Ahn YJ, Vang L, McKeon TA, Chen GQ (2007) High-frequency plant regeneration through adventitious shoot formation in castor (Ricinus communis L.). Vitro Cell Dev Biol Plant 43:9-15. https://doi. org/10.1007/s11627-006-9009-2

Ballester A, San-Jose MC, Vidal N, Fernandez-Lorenzo JL, Vieitez AM (1999) Anatomical and biochemical events during in vitro 
rooting of microcuttings from juvenile and mature phases of chestnut. Ann of Bot 83:619-629. https://doi.org/10.1006/anbo. 1999.0865

Compton ME (1994) Statistical methods suitable for the analysis of plant tissue culture data. Plant Cell Tissue Organ Cult 37:217242. https://doi.org/10.1007/BF00042336

Druege U, Franken P, Hajirezaei MR (2016) Plant hormone homeostasis, signaling, and function during adventitious root formation in cuttings. Front Plant Sci 7:381. https://doi.org/10.3389/fpls. 2016.00381

Fu Z, Xu P, He S, da Silva TJA, Tanaka M (2011) Dynamic changes in enzyme activities and phenolic content during in vitro rooting of tree peony (Paeonia suffruticosa Andr.) plantlets. Maejo Int J Sci Technol 5:252-265

Gordon SA, Weber RP (1951) Colorimetric estimation of indoleacetic acid. Plant Physiol 26(1):192-195. https://doi.org/ 10.1104/pp.26.1.192

Hartmann HT, Kester DE, Davies FT, Geneve R (2011) Propagation of ornamental trees, shrubs, and woody vines. Hartmann and Kester's Plant Propagation: Principles and Practices, 8th edn. Prentice Hall, Upper Saddle River, New Jersey, pp 774-839

Huang A, Wang Y, Liu Y, Wang G, She X (2019) Reactive oxygen species regulate auxin levels to mediate adventitious root induction in Arabidopsis hypocotyl cuttings. J Integr Plant Biol 62(7):912-926. https://doi.org/10.1111/jipb.12870

Ilczuk A, Jacygrad E (2016) The effect of IBA on anatomical changes and antioxidant enzyme activity during the in vitro rooting of smoke tree (Cotinus coggygria Scop.). Sci Hort 210:268-276. https://doi.org/10.1016/j.scienta.2016.07.036

Ilczuk A, Jagiełło-Kubiec K, Jacygrad E (2013) The effect of carbon source in culture medium on micropropagation of common ninebark (Physocarpus opulifolius (L.) Maxim.) 'Diable D'or. Acta Sci Pol. Hortorum Cultus 12(3):23-33

Jagiełło-Kubiec K, Nowakowska K, Ilczuk A, Łukaszewska AJ (2021) Optimizing micropropagation conditions for a recalcitrant ninebark (Physocarpus opulifolius L. Maxim.) cultivar. Vitro Cell Dev Biol Plant 57:281-295. https://doi.org/10.1007/ s11627-020-10154-0

Jensen WA (1962) Botanical histochemistry. San Francisco, Freeman and Co., Principles and practice, $\mathrm{p} 408$

De Klerk GJ, van der Kriken W, De Jong JC (1999) The formation of adventitious roots: new concepts, new possibilities. Vitro Cell Dev Biol Plant 35:189-199. https://doi.org/10.1007/ s11627-999-0076-Z

De Klerk GJ, Guan H, Huisman P, Marinova S (2011) Effects of phenolic compounds on adventitious root formation and oxidative decarboxylation of applied indole acetic acid in Malus 'Jork 9.' Plant Growth Regul 63:175-185. https://doi.org/10.1007/ s10725-010-9555-9

Lakehal A, Bellini C (2019) Control of adventitious root formation: Insights into synergistic and antagonistic hormonal interactions. Physiol Plant 165:90-100. https://doi.org/10.1111/ppl.12823

Li S, Xue L, Xu S, Feng H, An L (2007) Hydrogen peroxide involvement in formation and development of adventitious roots in cucumber. Plant Growth Regul 52:173-180. https://doi.org/10. 1007/s10725-007-9188-9

Li SW, Xue L, Xu S, Feng H, An L (2009) Hydrogen peroxide acts as a signal molecule in the adventitious root formation of mung bean seedlings. Environ Exp Bot 65:63-71. https://doi.org/10. 1016/j.envexpbot.2008.06.004

Mathesius U (2001) Flavonoids induced in cells undergoing nodule organogenesis in white clover are regulators of auxin breakdown by peroxidase. J Exp Bot 52:419-426. https://doi.org/10.1093/ jexbot/52.suppl_1.419
Millán-Orozco L, Corredoira E, San José MC (2011) In vitro rhizogenesis: histoanatomy of Cedrela odorata (Meliaceae) microcuttings. Rev Biol Trop 59(1):447-453. https://doi.org/10. 15517/RBT.V59I1.3211

Murashige T, Skoog F (1962) A revised medium for rapid growth and bio assays with tobacco tissue cultures. Physiol Plant 15:473497. https://doi.org/10.1111/j.1399-3054.1962.tb08052.x

Naija S, Elloumi N, Jbir N, Ammar S, Kevers C (2008) Anatomical and biochemical changes during adventitious rooting of apple rootstocks MM 106 cultured in vitro. C R Biol 331:518-525. https://doi.org/10.1016/j.crvi.2008.04.002

Neves C, Sa MC, Amancio S (1998) Histochemical detection of $\mathrm{H}_{2} \mathrm{O}_{2}$ by tissue printing as a precocious marker of rhizogenesis in grapevine. Plant Physiol Biochem 36:817-824. https://doi. org/10.1016/S0981-9428(99)80019-9

Pacholczak A (2015) The effect of the auxin application methods on rooting of Physocarpus opulifolius Maxim. cuttings. Propag Ornam Plants 15(4):147-153

Pacholczak A, Szydło W (2008) Effect of ammonium zinc acetate on rooting of stem cuttings in Physocarpus opulifolius. Ann Warsaw Univ of Life Sci 29:59-64

Pacurar DI, Perrone I, Bellini C (2014) Auxin is a central player in the hormone cross-talks that control adventitious rooting. Physiol Plant 151:83-96. https://doi.org/10.1111/ppl.12171

Pasternak T, Potters G, Caubergs R, Jansen MAK (2005) Complementary interactions between oxidative stress and auxins control plant growth responses at plant, organ, and cellular level. J Exp Bot 56(4180):1991-2001. https://doi.org/10.1093/jxb/ eri196

Pick E, Keisari YA (1980) A simple colorimetric method for the measurement of hydrogen peroxide produced by cells in culture. J Immunol Methods 38:161-170. https://doi.org/10.1016/00221759(80)90340-3

Polska Norma [Polish Norm] PN-91/R-87019 (2002) Pharmacopoea Polonica VI. Polskie Towarzystwo Farmaceutyczne, Warszawa: 895-897 (In Polish)

Rout GR (2006) Effect of auxins on adventitious root development from single node cuttings of Camellia sinensis (L.) Kuntze and associated biochemical changes. Plant Growth Regul 48:111117. https://doi.org/10.1007/s10725-005-5665-1

Sharma A, Shahzad B, Rehman A, Bhardwaj R, Landi M, Zheng B (2019) Response of phenylpropanoid pathway and the role of polyphenols in plants under abiotic stress. Molecules 24(13):2452. https://doi.org/10.3390/molecules 24132452

Shekhawat MS, Manokari M (2016) In vitro propagation, micromorphological studies and ex vitro rooting of cannon ball tree (Couroupita guaianensis Aubl.): a multipurpose threatened species. Physiol Mol Biol Plants 22:131-142. https://doi.org/10. 1007/s12298-015-0335-x

Szydło W, Pacholczak A, Łukaszewska A (2007) Rooting of stem cuttings of Hedera helix 'Arborescens' as affected by zinc treatment. Ann Warsaw Univ of Life Sci 28:79-86

Tomač T, Obert B, Rolčik J, Sămaj J (2016) Improvement of adventitious root formation in flax using hydrogen peroxide. New Biotechnoly 33(5):728-734. https://doi.org/10.1016/j.nbt.2016. 02.008

Tsukagoshi H (2016) Control of root growth and development by reactive oxygen species. Curr Opin Plant Biol 29:57-63. https:// doi.org/10.1016/j.pbi.2015.10.012

Tyburski J, Jasionowicz P, Tretyn A (2006) The effects of ascorbate on root regeneration in seedling cuttings of tomato. Plant Growth Regul 48:157-173. https://doi.org/10.1007/ s10725-005-5991-3

Vidal N, Arellano G, San-Jose MC, Vieitez AM, Ballester A (2003) Developmental stages during the rooting of in-vitro-cultured 
Quercus robur shoots from material of juvenile and mature origin. Tree Physiol 23(18):1247-1254. https://doi.org/10.1093/ treephys/23.18.1247

Wei K, Ruan L, Wang L, Cheng H (2019) Auxin-induced adventitious root formation in nodal cuttings of camelia sinensis. Int J Mol Sci 20(19):4817. https://doi.org/10.3390/ijms/20194817

Wiszniewska A, Nowak B, Kołton A et al (2016) Rooting response of Prunus domestica L. microshoots in the presence of phytoactive medium supplements. Plant Cell, Tiss Organ Cult 125(1):163176. https://doi.org/10.1007/s11240-015-0937-6

Wójcik AR, Laudański Z (1989) Statistical planning and concluding in experimental works. [Planowanie i wnioskowanie statystyczne w doświadczalnictwie]. Wydawnictwo Naukowe PWN, Warszawa, p 130 (In Polish)
Yan H, Liang C, Yang L, Li Y (2010) In vitro and ex vitro rooting of Siratia grosvenorii, a traditional medicinal plant. Acta Physiol Plant 32:115-120. https://doi.org/10.1007/s11738-009-0386-0

Yang W, Zhu C, Ma X, Li G, Gan L, Ng D, Xia K (2013) Hydrogen peroxide is a second messenger in the salicylic acid-triggered adventitious rooting process in mung bean seedlings. PLOS ONE 8(12):e84580. https://doi.org/10.1371/journal.pone.0084580

Publisher's Note Springer Nature remains neutral with regard to jurisdictional claims in published maps and institutional affiliations. 